\title{
Exploring the Prevalence of Abortion and its impact on the Academic Performance of Medical Female Students in Delta State University, Abraka
}

\author{
Nwogueze Bartholomew Chukwuebuka ${ }^{1 *}$ and Daubry Tarela Melish Elias ${ }^{2}$ \\ ${ }^{1}$ Department of Human Physiology, College of Health Sciences, Evangel University, Akaeze, Ebonyi State Nigeria \\ ${ }^{2}$ Department of Human Physiology, Faculty of Basic Medical Sciences, Delta State University, Abraka, Nigeria.
}

\begin{abstract}
This study examined the prevalence of abortion and its impact on the academic performance of medical female students in Delta State University, Abraka. Descriptive survey method was employed for the study while simple random sampling technique was utilized in selecting a target sample size of 164 female medical students from a population of 1,640 across five departments in the College of Health Sciences, Delta State University Abraka. Self-designed instrument was used as the instrument for data collection. 150 copies of the questionnaire were successful retrieved from the field and were used for data analysis. Frequency count and percentages was employed as the statistical technique for data analysis. Results obtained from this study revealed the following findings; abortion is prevalent among the female medical students leaving off-campus. Factors that influences female medical students include; poverty and financial concern, psychological factor, maternal and social factors, peer group influence and poor knowledge of the risk factors behind abortion. Consequences of abortion include; the risk of anxiety and depression, negative impact on the academic outcome, leads to school drop-out among female students, lower degree of social support, abandonment and rejection from family's member and deprives the female student from regular reading. Therefore, strategies for preventing the negative effects caused by abortion include; educating the female medical student on the need to always use contraceptive, always organize seminars to inform the female student of the consequences of abortion, formulation polices that allows for disciplinary measures on victims of abortion and providing early sexuality education earlier for the female child.
\end{abstract}

Keywords:- Prevalence, Abortion, Medical, Academic Performance, Female Students.

\section{INTRODUCTION}

Abortion is a global public health issue and an important barrier to effective academic performance of the female students. The term 'Abortion' connotes the removal or expulsion of an unwanted pregnancy embryo or fetus from the uterus either usually about the 20th week of gestation (World Health Organization, 2020). Abortion therefore implies the termination of pregnancy prior to the time the fetus is able to survive. Potts, Diggory and Peels, (1977) sees abortion as a loss of pregnancy before the fetus or fetuses are potentially capable of life independent of the mother. Abortion remains one of the leading causes relating to issues of maternal mortality and morbidity around the world, especially, in Nigeria (Adinma, 2011). Hence, unwanted pregnancies in youths and complications of induced abortions are an important health problem in the world (WHO, 2011).

From time immemorial, the prevalence of abortion among students has existed and victims are often subjected to stigmatization (Charles, Polis, Sridhara \& Blum, 2008). Inspired by a incessant fear of the disgrace from the general public, female students at tertiary schools will in general prematurely end or end undesirable pregnancies attributable to such a significant number of reasons extending from assault, uncertain sexual accomplices, tyrant guardians, poor financial conditions and friend impact to ineptness of parenthood (Ajadi, 2009). At the point when female understudies understand that they have been impregnated by hitched and additionally more established sexual accomplices who are jobless, they are bound to settle on fetus removal so that their contemplates don't turn out to be unfavorably influenced (Patel and Kooverjee, 2009).

The prevalence of abortion among female medical students has resulted in a difficult feeling for the individual, both at a physical and mental level. Aware of the social shame of having undesirable pregnancies, numerous little youngsters who become pregnant look for premature birth as the best way to end undesirable pregnancies. So, it is but obvious to have some of complications after undergoing medical and surgical abortions (Carlsson, Breding and Larsson, 2018). Some female students experience feelings of guilt, sadness, remorse, shame, anger, and sadness following an abortion. These feelings probably indicate that they are experiencing normal grief and distress about all of the things they have been through. Beside the risks of unsafe abortion there are serious health risk complications involved in child bearing as an adolescent or teenager, they include; greater risk of pelvic bone immaturity, prolonged labour and otherwise difficult birth experience (Otoide et al., 2011).

Academic performance implies the scores or examination grade a student obtained at the end of a final year examination. Laosa, (2005) sees academic performance as the core of pillars on which the entire future personality stands. Academic performance has always been the centers of academic development of the child and it 
remains the most important goal of education. Academic performance of students can greatly be determined by a factors ranging from those present in the learner to those within the modifiable factors of the home of the student (Muhamed and Muhamed, 2010). One of the commonest issues facing undergraduate students is unwanted pregnancy followed by abortion (Adewole et al, 2002).

In all, the incidence of abortion among female students has continued to be a very controversial and complex issue given its political, ethical, religious, and health dimensions which often lead to heated debates in public forums. In Nigeria, reports have it that $20 \%-40 \%$ of maternal deaths are linked to abortions (Oriji et al, 2009), with 610,000 abortions occurring yearly (Henshaw et al, 1998). The prevalence of abortion particularly among female students are; incidence of school drop-out and performing poorly in examinations, hence, when a young female becomes pregnant her physical, social, educational and career development is significantly altered (Cordingley 2014). Unfortunately, an unwanted child has consequences for the mother's socioeconomic status, her educational attainment, her health, and her family development and this has serious economic and social repercussions for the larger society.

\section{MATERIALS AND METHODS}

\section{$>$ Design of the Study}

The study employed descriptive survey research design. This design was chosen to enable the researcher to directly investigate the phenomenon. According to Lockesh (1984) the choice for descriptive design is to attain applicable and preserved information concerning the position of phenomena and whenever possible to draw valid general conclusion for the data discovered.

\section{Participants}

The participants for the study comprises of medical female students from the five departments under the college of health science in Delta State University Abraka, namely; Anatomy, Physiology, Medical Biochemistry, Nursing Science and Medicine and Surgery respectively. The estimated population of female students sampled for this study is 1,640 respondents.

\section{> Sample and Sampling Technique}

The sample size for this study is 164 female medical students which constitute $10 \%$ of the target population of the study. This concurs with the concept of Best and Kaln (2006) who argue that the ideal sample of a large population should be small enough to be selected economically. The simple random sampling technique was employed for this purpose. This technique used balloting on piece of paper which allows the researcher to select a subset that will represent the total population without bias.

\section{Instrument for Data Collection}

A self-designed and structured questionnaire was employed in collecting the data. The instrument consists of two parts and was made up of 24 items with two sections A and B. Section A contains the respondent personal data with 4 items while section B is made up of 20 items which were formulated by the researcher to access the consequences of abortion on female students' academic performance. Using the four point type Likert scale, the participants were supposed to indicate their options by putting a tick $(\sqrt{ })$ in the appropriate spaces provided.

\section{Validity of the Instrument}

The draft copy of the questionnaire alongside the research questions and purpose of the study were submitted to the researcher's supervisor and two other lecturers in the Department of Human Physiology, Delta State University Abraka to ascertain the face and content validity. They were requested to check for the suitability of the language and appropriateness of the items for the study. There corrections and contributions were noted after which some items were restructured while others were dropped.

\section{$>$ Reliability of Instrument}

To establish the reliability of the instrument, the instrument was administered on thirty (30) students who were not part of the respondents for the study. The Splithalf technique was used in testing for internal consistency and reliability of the instrument. The reliability co-efficient (r) obtained was 0.78 which showed that the instrument was reliable.

\section{Method of Data Collection}

The researcher working with two trained assistants administered the questionnaire to the participants who were requested to carefully make responses after which the copies of the instrument were retrieved. Out of the 164 questionnaires distributed 150 were successfully retrieved while 14 were lost accounting for $91.5 \%$ of the response rate as shown in Table 1 below:

\begin{tabular}{|c|c|c|}
\hline Response rate of questionnaire & Level of Responses & Percentage (\%) \\
\hline Number retrieved & 150 & 91.5 \\
\hline Number lost & 14 & 8.5 \\
\hline Total number distributed & 164 & 100 \\
\hline
\end{tabular}

Table 1:- Distribution of questionnaire

Sources: Survey Field, (2020) 


\section{Method of Data Analysis}

The method of data analysis that was employed is the simple percentage and frequency methods alongside tabular presentation in which descriptive analysis was used to infer meaning to the data in each table. The frequency of each response were calculated and converted to percentages of the total responses for each item in the questionnaire as shown in the formula below:

S.P $=\frac{F}{N} \mathrm{X} 100 \%$

Where: S.P = Simple Percentage

$\mathrm{F}=$ No of Frequency

$\mathrm{N}=$ Total number of Respondents

$\%=$ Percentage

III. RESULTS

\begin{tabular}{|c|c|c|}
\hline Level & Frequency(n) & Percentage (\%) \\
\hline 100 & 40 & 26.7 \\
\hline 200 & 40 & 26.7 \\
\hline 300 & 35 & 23.3 \\
\hline 400 & 35 & 23.3 \\
\hline TOTAL & $\mathbf{1 5 0}$ & $\mathbf{1 0 0}$ \\
\hline
\end{tabular}

Table 2:- Academic Levels of Respondent

Sources: Survey Field, (2020)

Table 2 above shows that a frequency of 40(26.7\%) out of the total sampled respondents were 100 and 200 level female students respectively; this was immediately followed by a frequency of 35(23.3\%) respondent that were in 300 and 400 levels, respectively.

\begin{tabular}{|c|c|c|}
\hline Age & Frequency (n) & Percentage (\%) \\
\hline 16-20years & 98 & 65.3 \\
\hline 21-25years & 28 & 18.7 \\
\hline 26years and above & 24 & 16 \\
\hline Total & $\mathbf{1 5 0}$ & $\mathbf{1 0 0}$ \\
\hline
\end{tabular}

Table 3:- Age Distribution of Respondents

Sources: Survey Field, (2020)

From table 3 above it was discovered that 98 female students' constituting approximately $65.3 \%$ of the sampled population fall within the age bracket of 16-20years, 28 of the female students' constituting $18.7 \%$ fall within that age bracket of $21-25 y e a r s$ and the remaining 24 female students' constituting 16\% fall within the age bracket of 26years and above.

\begin{tabular}{|c|c|c|}
\hline Religion & Frequency (n) & \multicolumn{2}{|c|}{ Percentage (\%) } \\
\hline Christian & 119 & 6 \\
\hline Muslim & 9 & 14.7 \\
\hline Others & 22 & $\mathbf{1 0 0}$ \\
\hline Total & $\mathbf{1 5 0}$ & \\
\hline
\end{tabular}

Table 4:- Religion of Respondents

Sources: Survey Field, (2020)

From the result of the data obtained in Table 4, it was revealed that out of the 150 persons sampled, 119 consisting approximately $79.3 \%$ were Christians, while, 9 respondents representing 6\% were Muslims and the remaining 22(14.7\%) were neither Christians nor Muslims. This shows that majority of the female students for the study in Delta State University Abraka are Christians.

\begin{tabular}{|c|c|c|}
\hline Marital status & Frequency (n) & Percentage (\%) \\
\hline Married & 39 & 26 \\
\hline Single & 111 & 74 \\
\hline Total & $\mathbf{1 5 0}$ & $\mathbf{1 0 0}$ \\
\hline
\end{tabular}

Table 5:- Marital status of Respondents

Source: fieldwork, (2020) 
Table 5 above shows that a frequency of $111(74 \%)$ of the total sampled population were unmarried respondents (singles) when compared to the remaining $39(26 \%)$ that were married. This indicated that majority of the female respondents that participated in this research were still singles.

\begin{tabular}{|c|c|c|c|c|c|c|c|c|c|}
\hline $\mathbf{S} / \mathbf{N}$ & ITEM & SA & $\%$ & $\mathbf{A}$ & $\%$ & D & $\%$ & SD & $\%$ \\
\hline 1. & $\begin{array}{l}\text { Abortion is not common among female } \\
\text { students in the medical school }\end{array}$ & 70 & 46.7 & 65 & 43.3 & 10 & 6.7 & 5 & 3.3 \\
\hline 2. & $\begin{array}{l}\text { Poor attitude towards abortion is most } \\
\text { prevalent among female undergraduates } \\
\text { leaving off-campus }\end{array}$ & 62 & 41.3 & 51 & 34 & 30 & 20 & 7 & 4.7 \\
\hline 3. & $\begin{array}{l}\text { Incidence of abortion is prevalent among } \\
\text { female students from poorer homes }\end{array}$ & 20 & 13.3 & 12 & 8 & 80 & 53.3 & 38 & 25.4 \\
\hline 4. & $\begin{array}{l}\text { Prevalence of abortion is high due to } \\
\text { incidence of sexual promiscuity }\end{array}$ & 45 & 30 & 76 & 50.7 & 25 & 16.7 & 4 & 2.6 \\
\hline 5. & $\begin{array}{l}\text { Lack of parental supervision forces most } \\
\text { female students to become victims of } \\
\text { abortion }\end{array}$ & 67 & 44.7 & 49 & 32.7 & 22 & 14.7 & 12 & 8 \\
\hline
\end{tabular}

Table 6:- Extent to which Abortion is prevalent among female medical students

Source: Fieldwork, (2020)

Key: SA- Strongly Agree, A-Agree, D-Disagree, SDStrongly Disagree, $\%$ - Percentage

Table 6 represents the responses on the Extent to which abortion is prevalent among female medical students in Delta State University, Abraka. In item 1, 90\% of the participants jointly supported the view that abortion is not common among female students in the medical school when compared to the remaining $10 \%$ that rejected the view. In item $2,75.3 \%$ jointly accepted the opinion that poor attitude towards abortion is most prevalent among female undergraduates leaving off-campus when compared to $24.7 \%$ that holds a contrary opinion. However, in item 3 , $78.7 \%$ of the participants rejected the fact that the incidence of abortion is prevalent among female students from poorer homes when compared to $21.3 \%$ that accepted the view. Consequently, in item $4,80.7 \%$ of the participants jointly supported the view that abortion among student is prevalent due to incidence of sexual promiscuity when compared to $19.3 \%$ that disagreed with the view. Nevertheless, in item 5 $77.4 \%$ of the respondents were jointly satisfied with the view that lack of parental supervision forces most female students to become victims of abortion when compared to a fewer percentage of $22.7 \%$ that holds a contrary opinion.

\begin{tabular}{|c|c|c|c|c|c|c|c|c|c|}
\hline S/N & ITEM & SA & $\mathbf{\%}$ & $\mathbf{A}$ & $\mathbf{\%}$ & $\mathbf{D}$ & $\mathbf{\%}$ & SD & \% \\
\hline 6. & Poverty and financial concern & 102 & 68 & 34 & 22.7 & 10 & 6.7 & 4 & 2.7 \\
\hline 7. & Psychological factor & 41 & 27.3 & 78 & 52 & 12 & 8 & 19 & 12.7 \\
\hline 8. & Maternal and social factors & 40 & 26.7 & 56 & 37.3 & 40 & 26.7 & 14 & 9.3 \\
\hline 9. & Peer group influence & 51 & 34 & 92 & 61.3 & 5 & 3.3 & 2 & 1.3 \\
\hline 10. & $\begin{array}{c}\text { Poor knowledge of the risk factors behind } \\
\text { abortion }\end{array}$ & 47 & 31.3 & 72 & 48 & 20 & 13.3 & 11 & 7.3 \\
\hline
\end{tabular}

Table 7:- Factors that influence female medical students to get involved in Abortion Source: Fieldwork, (2020)

Key: SA- Strongly Agree, A-Agree, D-Disagree, SDStrongly Disagree, $\%$ - Percentage

From Table 7 represents the responses obtained from the respondents based on factors that influence medical female students to get involved in abortion in Delta State University, Abraka. The respondents on a percentage of $90.7 \%$ were satisfied with the fact that poverty and financial concern influences the female medical students when compared to the remaining $9.3 \%$ that were not satisfied with the opinion. In item 7, 79.3\% jointly believed that psychological factor influences the female medical students when compared to the remaining $20.7 \%$ that rejected the view. In item $8,54 \%$ were of the opinion that maternal and social factors to some extent influences the female medical students to get involved in abortion when compared to the remaining $46 \%$ that were not comfortable with the view. Furthermore, in item 9, 95.3\% jointly agreed with the view that peer group influence the female medical students when compared to the remaining $4.7 \%$ with a different view. In item $10,79.3 \%$ jointly agreed that poor knowledge of the risk factors behind abortion promotes incidence of abortion among female medical students when compared to the other $20.7 \%$ that rejected the view. 
ISSN No:-2456-2165

\begin{tabular}{|c|c|c|c|c|c|c|c|c|c|}
\hline S/N & ITEM & SA & \% & A & \% & D & \% & SD & \% \\
\hline 11. & $\begin{array}{c}\text { Increased risk of anxiety and depression } \\
\text { during examinations }\end{array}$ & 72 & 48 & 44 & 29.3 & 18 & 12 & 16 & 10.7 \\
\hline 12. & $\begin{array}{c}\text { Negative impact on the academic outcome of } \\
\text { female medical students }\end{array}$ & 40 & 26.7 & 98 & 65.3 & 10 & 6.7 & 2 & 1.3 \\
\hline 13. & $\begin{array}{c}\text { Abortion leads to school drop-out among } \\
\text { female medical students }\end{array}$ & 43 & 28.6 & 106 & 70.7 & 1 & 0.7 & 0 & 0 \\
\hline 14. & $\begin{array}{c}\text { Lower degree of social support, abandonment } \\
\text { and rejection from family members }\end{array}$ & 71 & 47.3 & 70 & 46.7 & 7 & 4.7 & 2 & 1.3 \\
\hline 15. & $\begin{array}{c}\text { Deprives the female medical student from } \\
\text { regular reading }\end{array}$ & 69 & 46 & 68 & 45.3 & 9 & 6 & 4 & 2.7 \\
\hline
\end{tabular}

Table 8:- Consequences of abortion on the academic performance of the female medical students Source: Fieldwork, (2020)

Key: SA- Strongly Agree, A-Agree, D-Disagree, SDStrongly Disagree, \% - Percentage

Table 8 represents the responses obtained based on the consequences of abortion on the academic performance of female medical students in Delta State. In item 11, 77.3\% of the participants jointly accepted that abortion leads to increase in the risk of anxiety and depression during examinations when compared to $22.7 \%$ that holds a contrary opinion. In item $12,92 \%$ of the participants were satisfied with view that abortion has negative impact on the academic outcome of female medical students when compared to the remaining $8 \%$ that holds a negative opinion to this view. In item $13,99.3 \%$ of the participants were satisfied with the view that abortion leads to school drop-out among female medical students when compared to only $0.7 \%$ that holds a contrary view. In item $14,94 \%$ of the participants accepted the view that abortion could result to lower degree of social support, abandonment and rejection from family members when compared to $6 \%$ that holds different perspective. In item $15,91.3 \%$ accepted the view that abortion deprives the female medical student from regular reading when compared to $8.7 \%$ that holds a contrary perception.

\begin{tabular}{|c|c|c|c|c|c|c|c|c|c|}
\hline $\mathbf{S} / \mathbf{N}$ & ITEM & SA & $\%$ & $\mathbf{A}$ & $\%$ & D & $\%$ & SD & $\%$ \\
\hline 16. & $\begin{array}{l}\text { Educate female students on the need to } \\
\text { always use contraceptive }\end{array}$ & 90 & 60 & 45 & 30 & 10 & 6.7 & 5 & 3.3 \\
\hline 17. & $\begin{array}{l}\text { Organize seminars frequently to enlighten the } \\
\text { female student on the consequences of } \\
\text { abortion }\end{array}$ & 57 & 38 & 83 & 53.4 & 8 & 5.3 & 2 & 1.3 \\
\hline 18. & $\begin{array}{l}\text { Formulation of polices that allows for } \\
\text { disciplinary measures of abortion victims }\end{array}$ & 68 & 45.3 & 53 & 35.3 & 22 & 14.7 & 7 & 4.7 \\
\hline 19. & $\begin{array}{l}\text { Sexuality education should be made available } \\
\text { early at the child's education }\end{array}$ & 50 & 33.3 & 70 & 46.7 & 16 & 10.7 & 14 & 9.3 \\
\hline 20. & $\begin{array}{l}\text { University management should ensure that } \\
\text { there are counseling units to discourage the } \\
\text { female students from undertaking abortion }\end{array}$ & 60 & 40 & 31 & 20.7 & 20 & 30 & 29 & 19.3 \\
\hline
\end{tabular}

Table 9:- Strategies to reduce the impact of abortion on the academic performance of female medical students

Source: Fieldwork, (2020)

Key: SA- Strongly Agree, A-Agree, D-Disagree, SDStrongly Disagree, $\%$ - Percentage

Table 9 represents responses on the strategies to reduce the impact of abortion on the academic performance of female medical students in Delta State University, Abraka. In item 16, $90 \%$ of the participants were of the view that abortion could be reduced by educating the female students on the need to always use contraceptive whereas; the remaining $10 \%$ holds a different view. In item $17,91.4 \%$ of the participants jointly believed that abortion could be prevented by organizing seminars frequently to enlighten the female student on the consequences of abortion when compared to a percentage of $8.6 \%$ that rejected the view. In item $18,80.6 \%$ of the respondents jointly accepted the view that abortion could be prevented through formulation of polices that allows for disciplinary measures of abortion victims when compared to $19.4 \%$ that holds a contrary view. In item 19 , it was noted that $80 \%$ of the participants accepted the view that sexuality education should be made available early at the child's education when compared to the remaining $20 \%$ that rejected the view. Finally, it was observed that $60.7 \%$ of the participants jointly supported the view that university management should ensure that there are counseling units to discourage the female students from undertaking abortion when compared to a higher percentage of $39.3 \%$ that sees it from another perspective. 


\section{DISCUSSION}

The prevalence of abortion has attracted substantial attention in recent times in Nigeria and everywhere in the world; abortion has therefore become a global issue. Findings from this study has revealed that abortion is not common among female students in Delta State University Abraka, however, poor attitude towards abortion is most prevalent among female undergraduates leaving offcampus, also, the incidence of abortion is prevalent among female students from poorer homes, and such prevalence was due to the incidence of sexual promiscuity. Consequently, lack of parental supervision forces most female students to become victims of abortion. This research finding was similar with the observations of WHO (2006); Cheng, (2008), and Negedu, (2001) that aptly confirmed that unwanted pregnancies and abortions are indeed on the increase among female adolescent students with consequences on their health and performance in school.

The study revealed that the following factors are capable of influencing the female medical students towards getting involved in abortion; poverty and financial concern, psychological factor, maternal and social factors, peer group influence and poor knowledge of the risk factors behind abortion. This finding agrees with the opinion of Thompson and Crase (2009) who affirmed that students from poor socio-economic status have higher tendency towards abortion. The finding is also supported by Varga (2002) who noted that abortion is largely attributable to poor communication about sexual matters between parents and their daughters.

The possible consequences of abortion on the academic performance of the female students included; the risk of anxiety and depression, negative impact on the academic outcome, leads to school drop-out among female students, lower degree of social support, abandonment and rejection from family members and deprives the female student from regular reading. This is consistent with the findings of Bachiochi, (2005) that complications such as; heavy, incessant bleeding, organ damage caused by perforated uterus, infections, vulnerability, confusion, anxiety and depression are associated with abortion among female students.

Finally, the following strategies were adopted to reduce the impact of abortion on the academic performance of female medical students; educating female students on the need to always use contraceptive, organizing of seminars frequently to enlighten the female students of the consequences of abortion, formulation of polices that allows for disciplinary measures of abortion victims, providing sexuality education earlier at the child's education and organizing counseling units to help discourage the female students from undertaking abortion. This falls in line with the recommendation of Olaitan, (2010) that proper education should be given to young ladies and boys about preventive methods of unsafe abortion. However, it was noted that organizing youth centers to discourage students from undertaking abortion by Government and NGOs are not paramount in remedying the consequences of abortion in Delta State University, Abraka.

\section{CONCLUSION}

Globally, abortion has been proven to be one of the most prevalent gynaecological experiences prevalent among youths. Findings from our study has established that poor attitude towards abortion are responsible for such prevalence especially as observed among the female students leaving off-campus and this was attributed to poverty and financial concern, psychological, maternal and social issues, peer group influence and poor knowledge of the risk associated abortion. Thus, it has become obvious that abortion has negative impact on the academic performance of female medical students in Delta State University, Abraka.

\section{Ethics and consent}

Approval for this study was obtained from the Bioethics and Research Committee of the Faculty of Basic Medical Sciences, Delta State University Abraka.

\section{Funding information}

The study was self-sponsored by authors. No external funding was received.

\section{REFERENCES}

[1]. Adewole IF, Oye-Adeniran BA, Iwere N, Oladokun O, Gbadegesin A, Babarinsa AI. Contraceptive usage among abortion seekers in Nigeria. W. Afr. $J$. Med. (2002), 21(2):112-114

[2]. Adinma, E. 'Unsafe abortion and its ethical, sexual and reproductive right implication,' West African Journal of Medicine, (2009), 30(4): 245-249

[3]. Ajadi, A.O. Causes and consequences of induced abortion among university undergraduates in Nigeria. [Published Doctoral thesis]. Lagos: Lagos State University. (2009).

[4]. Bachiochi, E. "How Abortion Hurts Women: The Hard Proof." Crisis (2005), 23:6 [On-line] Available: http://erika.bachiochi.com/ Retrieved 04 August 2019.

[5]. Carlsson, I., Breding, K. \& Larsson, P. Complications related to induced abortion: a combined retrospective and longitudinal follow-up study. BMC Women's Health (2018), 18, 158

[6]. Charles, V.E., Polis, C.B., Sridhara, S.K. and Blum, R.W. Abortion and long-term mental health outcomes: a systematic review of the evidence. Contraception, (2008), 78(6), 436-450.

[7]. Cheng, L. "Surgical versus medical methods for second-trimester induced abortion". The WHO Reproductive Health Library. World Health Organization. (2008): Archived from the original on 17 February 2020. 
[8]. Cordingley, K. 'Underground Abortions in Nigeria,' (2014); Retrieved 13 March 2019, http://www.borgenmagazine.com/undergroundabortions-nigeria/,

[9]. Henshaw SK, Singh S, Oye-Adeniran BA, Adewole IF, Iwere N, Cuca YP. The incidence of induced abortion in Nigeria. Int Fam Plann Persp. (1998), 24(4):156-164.

[10]. Laosa, LM. "The Effects of Pre-School on Educational Achievement." A working paper. (2005): 1-14.

[11]. Muhamed, AK and Muhamed, FJ. "The Impact of Parental Socioeconomic Status on the Students' Educational Achievements at Secondary Schools." The J. Sci. Res. (2010), 6(6):678-687

[12]. Negedu, B. Nigeria: 4.4 Million Teenagers Engage in Abortion Annually-Expert http://allafrica.com/stories/201107111356.html (Accessed October 14, 2019).

[13]. Olaitan, OL. Knowledge of female genital cutting among parents in south west Nigeria. Translational Biomed. J., (2010), 1(2): 39-40.

[14]. Oriji VK, Jeremiah I, Kasso T. Induced abortion amongst undergraduate students of University of Port Harcourt. Nig J Med. (2009), 18(2):199-202.

[15]. Otoide, VO, Oronsaye, F \& Okonofua, FE. 'Why Nigerian adolescents seek abortion rather than contraception, evidence from focus group discussions,' International Family Planning Perspective, (2011), 27(2): 77-81.

[16]. Patel, C.J. and Kooverjee, T. Abortion and contraception: attitudes of South African university students. Health Care Women International; (2009), 30(6):550-68.

[17]. Potts, M., Diggory, P., Peel, J. Abortion. Cambridge: Cambridge University Press. (1977) pp.433

[18]. Thompson, S.D. and Crase, S.J. Fathers of infants born to adolescent mothers: a comparison with nonparenting male peers and adolescent mothers. Children and Youth Service Review, (2004), 26:489505.

[19]. Varga, C.A. Pregnancy termination among South African adolescents. Studies in Family Planning, (2002), 33: 283-298.

[20]. World Health Organization, 'Intervention for preventing unintended pregnancies among adolescents,' WHO Reproductive Health Library, (2020), Retrieved 21 June 2020, http://apps.who.int/rhl/adolescent/cd005215_ramoss_c om/en/

[21]. World Health Organization, 'Unsafe abortion, Global and regional estimates of the incidence of unsafe abortion and associated mortality in 2008; (2005)

[22]. World Health Organization. Reproductive Health. Managing complications in pregnancy and childbirth: a guide for midwives and doctors. World Health Organization. (2006). 